\title{
The Impacts of Tourism on Cultural Identity on Lisbon Historic Neighbourhoods
}

\author{
Pauline Daly ${ }^{\mathrm{a}}$, Álvaro Dias ${ }^{1 \mathrm{a}, \mathrm{b}}$ and Mafalda Patuleia ${ }^{\mathrm{a}, \mathrm{c}}$ \\ a. Universidade Lusófona de Humanidades e Tecnologias, Portugal. \\ b. ISCTE-IUL, Portugal \\ c. GOVCOPP, Portugal
}

\begin{abstract}
In the past last decades tourism was long perceived as a solution to remediate to economic crisis and recessions, while the impacts were secondary and weren't qualified. Focusing of the consequences of tourism development, the identities of historic urban areas were constantly been neglected as essential features and symbols of their attractiveness. However, long before tourism, modifications of cities spatial structures and social geography were conducted by governments as strategies to repopulate certain urban areas abandoned for historical or economic reasons. For instance, through gentrification, urban rehabilitation or revitalisation, the urban structures became more appealing and attracted investments that strengthen local economies. Nevertheless, these transformations have dismantled cultural patterns and were amplified by touristification. This investigation deals with gentrification and urban rehabilitation as precursors of tourism growth and how it influences a neighbourhood's cultural identity. Using a historic touristic destination as an example gave leverage to the understanding of the repercussions. Lisbon historic neighbourhoods; Alfama, Mouraria and Bairro Alto, influenced our understanding with the active participation of the residents as cocontributors of this research. Findings confronted our pre-existing understandings on tourism growth to the impacts generated on cultural identity.
\end{abstract}

Keywords: cultural identity, gentrification, multiculturalism, tourism, touristification.

Tourism is driven by consumption-led growth and the production of cultural images, and for some scholars, tourism development can be characterised as a process that involves social interactions, relations and conflicts (Gotham, 2005). While tourism growth modifies socio-cultural attributes, it can be questioned whether tourism development improves or deteriorates resident's quality of life. However, in order to understand the bigger picture that underlines tourism, this paper' opening introduces several notions that had to be considered.

While tourism can either be understood as a result of gentrification or a pre-condition (Gravari-Barbas \& Guinand, 2017), gentrification is affected by the changing patterns of tourism flows and is defined as a brutal change of landscapes. Nevertheless, the consequences of gentrification include social and cultural implications that rise upward tensions in local communities, disrupting the social cohesion and creating exclusions (Grewal et al., 2019; Parker, 2019; Sequera \& Nofre, 2018). These exclusions are supported by the touristification of certain spaces, responding then again to tourism flows. Touristification may be seen as a

\footnotetext{
${ }^{1}$ Corresponding Author E-Mail: alvaro.dias1@gmail.com
} 
vehicle for gentrification, that conducts a form of urban regeneration and socioeconomic revitalisation. However, some scholars questioned the real impacts of gentrification and opened discussion on whether gentrification could offer the possibility to improve the living conditions and be considered as a necessity for survival (Gravari-Barbas \& Guinand, 2017) or on the contrary, that gentrification should be resisted (Elliott-Cooper et al., 2019). While some are more concentrated towards the restoration of historic homes (Glass, 1964), the social diversification that it engenders (Lees et al., 2013) and the eventual economic benefits, others accentuated the inevitable spatial destruction of certain spaces (Cocola-Gant, 2015) and represented it as a socio-spatial process that answers to the needs of affluent residents and consumers, neglecting the lower-classes, which by all means are direct actors of the cultural image.

In this sense, diversification can be contextualised through residents, new gentrifiers or immigrants. Although multiculturalism can reinforce the ideal of tolerance and cultural heritage, it can also enhance disruption and loss of national identity (Foroutani, 2020; Vertovec \& Wessendorf, 2004), which eventually accentuated scholars' discussions towards the beneficence of diversified neighbourhoods. Through globalisation, multiculturalism can either be perceived as a cultural degradation and dissolvement, that accentuated the gentrification process and weakened local economies (Beckett \& Kobayashi, 2020; Fainstein, 2005; Yigit \& Tarman, 2013) or as a gain of attractiveness and precursor of economic added plus value through diversification (Rath, 2007). One of the challenges is to ascertain whether cohabitation between migrants, residents and tourists can be considered whilst preserving a cultural identity.

However, despite the actual literature on the subject, the subject remains underexplored. Thus, this investigation will procure a deepen insight on the impacts of tourism on cultural identity. To do so, the research distinguished numerous factors and contributors towards a more profound understanding; tourism developments and strategies, gentrification processes, touristified neighbourhoods and the unavoidable immigrations that cosmopolitan cities attract. And tended to highlight the eventual conflict between residents and tourists towards a preservation of heritage, opposing tourism development to a deterioration of place identity and quality of life (Bernardo et al., 2016).

The research approach aimed at answering the following questions: Can tourism be considered as a form of gentrification? Does tourism improve or deteriorate resident's quality of life? How can the cultural identity be influenced by tourism?

To enable this research with concrete examples, we contextualised our literatures with the case of Lisbon' historical neighbourhoods. Lisbon detains similar characteristics with other European cities; with a touristic demand focused on culture and authenticity. By been affluent and considered as a trending touristic destination, Lisbon' sudden tourism growth endangered the cultural identity that it once preserved. The case of Alfama, Mouraria and Bairro Alto are studied as examples of historical neighbourhoods that are been directed by tourism flows. To achieve our objectives: to understand the dimensions and repercussions of tourism development upon and within communities; to determinate the internal and external actors of spatial and cultural structures; and finally, to understand how tourism growth is a direct actor upon cultural identity loss, we leaned on residents' observations and participations, which permitted to extend our pre-existing understandings.

Thus, this article is structured as follow: the section one, mentioned above, gave an introduction to contextualise the research, pursued by the section two that is conducted through a selection of literatures that will be the base of our theory and will define our hypothesis; that gentrification, touristification, multiculturalism and cultural identity can all be vectors for modified cultures. To study further the subject, the methodology introduces the research technique used; a qualitative analysis, towards our case study; Lisbon' historic neighbourhoods. Section four presents the results and discussions. Finally, the investigation highlights the results in section five as potential issues to be studied more thoroughly. 


\section{Theoretical Framework}

\section{Overtourism and Touristification}

While discussing 'tourism' the term 'overtourism' designates the situation when local residents and tourists or visitors feel that the quality of life or the quality of an experience in a certain area has deteriorated due to an excessive number of tourists (Goodwin, 2017). In other words, it expresses the 'overuse' or 'overdevelopment' of a destination conducted by an overconcentration of tourists (Dobbs \& Butler, 2019). They argued that the concerns related to overtourism included the overconcentration of tourists in one place, tourists' maladaptive behaviours, dissensions between residents and tourists, cultural loss, a lessening of residents' quality of life and a diminution of attractiveness regarding tourists' perspective.

To be noted that overtourism occurs when areas are drowning from an excessive number of visitors, and mass tourism occurs when areas are able to cope with a large number of tourists. Perkumienè and Pranskūnienè's (2019) definition highlighted that "overtourism phenomenon is more related to perceptible tourism encounters, environmental changes, and violations of human life" (p. 6). Therefore, overtourism intervenes when the balance between the negative aspects of tourism outweighs the benefits (Andriyani, et al., 2019; Anuar et al., 2019). Goodwin (2017) argued that the causes of overtourism are simply the results of a freefall system that focused on the capital gains rather than the resulting disparities.

Alongside with the impacts of tourism itself, overtourism impacts on the lives of host communities by the basis of economic benefits, the grounds of social, cultural and environmental destructions. Koens et al. (2018) argued that overtourism shouldn't be studied as a tourism problem but as a social problem, which resulted from a failed system that focused on the capital gains rather than the resulting disparities; "the state of overtourism is a consequence of tourism using the destination rather than the destination using tourism" (Goodwin, 2017, p. 10).

Moreover, the term 'touristification' is used by scholars to express a certain 'visitor overkill' (Koens et al., 2018). Defining all the spatial, social, economic and cultural transformations linked to an increased presence of tourists. Therefore, destinations failure to properly address and manage tourism impacts imposes pressure on local communities physical and environmental aspects, stimulating disruption due to an increasing amount of concentration of visitors, leading to anti-tourism manifests (Kuščer \& Mihalic, 2019). The existence of resident protests amplifies the frustration and exasperation of certain communities that are powerless against such touristification. The economic growth is been prioritized over social and environmental repercussions (Dobbs \& Butler, 2019). Therefore, Dobbs and Butler (2019) researched raised the question of whether "overtourism can exist in location devoid of local residents?" (p. 2).

\section{Residents Perceptions and Attitudes}

The impacts of tourists on the social environment are based on the local communities' tolerance towards tourism and tourists (Koens et al., 2018). Doxey's irritation index (1975) was elaborated to mark the different stages of residents' attitudes towards tourism. Not only he provided evidence that the attitude of locals towards tourist is a volatile concept, he also provided different stages determining the evolution of their perception. Starting with the euphoria stage that illustrates a welcoming phase, to the stage of an apathy relationship between residents and visitors, through the stage of irritation that portraits negative behaviours and overcrowded spaces. 
Perceptions differ amongst residents; between the ones aware of the benefits and the ones enduring the costs (Koens \& Postma, 2017). Benefits can be illustrated as the economic gain and opportunities, such as real-estate and employment, and an economic support for social and cultural development. And negative impacts as the social exclusion brought by rising costs of living or an overall decrease of hospitality making the cities less attractive. Therefore, Pizam (1978) noted that the attitude varied whether an individual was economically dependent on tourism or not. And Lankford and Howard (1994) interpreted that economic dependency on tourism and resident's involvement in tourism decision making are two dimensions which varies residents' attitudes towards tourism.

By being cultural agents that enables tourism development (Muler Gonzalez et al., 2018) residents' attitudes towards tourists can influence a destination' hospitality and attractiveness. Residents protests and social movements emerged, just as the term 'tourismphobia', to describe a social discontent neglected by the pressures of tourism growth. First adopted by Spanish medias to emphasize the drastic changes occurring against the interests of local communities, generating inequalities and social exclusions (Milano et al., 2019). Seraphin et al. (2019) defined tourismphobia as "a lack of interaction between locals and visitors in destinations victim of overtourism. (...) due to the fact that the interests of locals and visitors are perceived by being contradictory, whereas they are actually complementary and interrelated" (p. 5). To be noted that the increase congestion and the privatisation of public places eventually echoes on the excessive number of tourists generating the loss of belonging and diminishing the sense of place (Milano et al., 2019). Meanwhile, resident support for tourism can be explained by the awareness of economic and cultural benefits, however, studies have shown that tourism effects on traditions, family values, cultural commercialization are direct consequences of residents' hospitality declination. To be noted that although residents may be perceived as favourable to tourism, it doesn't restrict them from having concerns for the health of their communities (Andereck et al., 2005; Dias et al., 2020).

Residents' discontentment reverberates the poor tourism development management (Seraphin et al., 2019), where overcrowded locations and visitor pressure disrupt local communities' daily life, draining all its sociocultural assets, eventually affecting the visitors' experience (Kuščer \& Mihalic, 2019). Doğan (1989) feared that tourists would cause the weakening of cultural traditions which would eventually create a certain hostile environment. For some scholars, hostility and resentment towards tourists are referred as the 'tourist impact on others' which assumes a certain superiority and invincibility detained by tourists, raising unfairness among residents. As a source of conflicts and disparities, tourism can amplify barriers between social groups. Doğan offered two scenarios; or the residents manifest a certain resistance to this touristification, or they incorporate tourism to their daily lives.

\section{Multiculturalism}

While 'tourist impact on others', immigrants are also counted in the equation. By definition, immigrant represents "a non-resident arriving in a state with the intention to remain for a period exceeding a year" and migrant refers to "a person who is outside the territory of the state of which they are nationals or citizens and who has resided in a foreign country for more than one year irrespective of the causes, voluntary or involuntary, and the means, regular or irregular, used to migrate" (EMN).

For many scholars, immigration allowed urban and rural demographic changes, representing an essential resource for the refinement of cities (Vertovec \& Wessendorf, 2004; Tarman \& Gürel, 2017). They emphasized the need for a cohabitation of different communities to promote integration and diversification. However, fundamental features such as the freedom of speaking their own language, engaging in the cultural institutions of their choosing and practicing their own religion can be at sake while fostering multiculturalism (Carothers, 2018; 
Johnson \& Hinton, 2019). The International Encyclopaedia of Social \& Behavioural Science (Smelser \& Baltes, 2001) defined 'multiculturalism' as the challenge that society has to cope with an ethnic diversity which mostly results from immigration (and ethnic minorities). Thus, two different perceptions: the perception of multiculturalism as the ideal of tolerance, equality and freedom, which integrates education, employment, religion, cultural heritage and language. Or the perception of multiculturalism as an ideal way to disrupt a national identity and to end the social cohesion (Vertovec \& Wessendorf, 2004) and to "erode civic virtues, identities and practices that are necessary (...)" (Levrau \& Loobuyck, 2018. p. 2).

Characterized as a 'feel-good celebration' of diversity that that encourages citizens to embrace the features of multi-ethnic groups. Kymlicka (2012) gave prominence to the empowerment that signified multiculturalism as the liberation of centuries of discriminations and racial segregations. By enabling equality, diversity and awareness, Fainstein (2005) argued that it can "attract human capital, encourage innovation, ensure fairness and (give) an equal access to a variety of groups" (p. 4), representing a key for growth and equity. Moreover, Fincher et al. (2014) pointed out that even though multiculturalism is perceived as a failure by some national leaders, many urban residents live happily within ethnic and racialized differences and neighbourhoods.

Whereas, diversity can also produce abhorrence through culture degradation and dissolvement. A mutual loathing that is highlighted as an issue for those who endure discriminations and for those who suffer from a loss of place and identity (Fainstein, 2005; Smith, 2020). An anti-migrant sentiment can take place when natives feel threatened by immigrants regarding their economic situation, political, cultural or even for their safety (Rustenbach, 2010). Creating a low life satisfaction, Safi (2009) argued that discrimination can obstruct immigrants' social and economic achievements and lower their well-being. Ethnic and racial discriminations obstruct the integration process (Maxwell, 2010).

Meanwhile, scholars and literatures have assimilated migration to tourism as a direct result of globalisation. For instance, Moufakkir (2014) argued that tourism represents "the freedom of mobility and right to travel" (p. 111). The effects of globalisation on mobility and accessibility enabled the creation of ethnic neighbourhoods (Krase, 2012), developed as spaces of leisure and consumption, which reverberates a certain diversification of the market (Rath, 2007). Thus, commodified and diversified neighbourhoods are precursors of tourism flows and immigrants are perceived as an economic added plus value through innovation and diversification, allowing cities to gain attractiveness (Gheasi et al., 2011; Rath, 2007).

Perceived as a diversification process, multiculturalism contributes to cultural and place marketing, constituting an asset for tourist experiences (Fincher et al., 2014). For instance, neighbourhoods such as 'Chinatown' or 'little Italy' can be interpreted as commercial ventures; their 'products' were first created to be consumed by ethnic groups, but were later on modified to be consumed by tourists (Rath, 2007). Or as a marketing strategy to internationalize cities and to promote place branding (Belabas et al., 2020). Increasing the cultural events, the ethnocultural neighbourhoods allowed residents and visitors to be part of diversified experiences (Vertovec \& Wessendorf, 2004).

However, while gaining attractiveness, many destinations tends to lose their identity along the way; commodified places can have impacts on the relation between individuals and their environment (Ujang, 2012). The term 'place attachment' is highlighted as the need for individuals to have a certain feeling of belonging, also related to the term 'place identity' which impacts on individuals' self-esteem and personal uniqueness (Gu \& Ryan, 2008). Racial, ethnic and class identity are social characteristics that tourism development tends to neglect while impacting directly on community's well-being. Ujang (2012) argued that "place identity is linked to meanings and perceptions held by the people in relation to their environment (and that) the loss of identity weakens the depth of meaning, attachment and diversity of place 
experience" (p. 156); culture influences place identity and emotions allows the development of place attachment.

However, by welcoming diversity through religion, linguistic or culture, many scholars discerned that cohabitation between migrants, residents and tourists can be delicate. The acceptance can be embedded by inequalities, identity and cultural loss, exclusion and loss of attractiveness, which can eventually lower the quality of life and well-being. Meanwhile, Rath (2007) argued that community's strength to accept modifications are "symbols of cultural diversity and an object of civic pride" (p. 10) that eventually foster' social cohesion (Watters et al., 2020).

\section{Gentrification}

Diversification is also interpreted by scholars as one of the 'gentrification' process results. During the late 70's the term 'gentrification' emerged to describe the sudden arrival of middle and upper classes into traditionally working-class neighbourhoods (Philips, 1993). Shifting from a desire for social mixing to a more individualistic concept, gentrification means the substitution of existing population by a gentry (Lees et al., 2013). Defined as a process of capital investment and a change of the social structure, Philips (1993) and Cocola-Gant (2018) called it the 'back to the city movement'. Assimilated to an urban rebirth post-recession, Lees (2000) perceived gentrification as a 'cure' for inner cities, driven mainly by investment flows, allowing an urban renaissance. Related to social, economic, cultural and physical transformations, gentrification is discerned as a displacement vector. Hence, Butler (2007) identified gentrification as a "process of class change; for some it is a process of colonising the city, for others a manifestation of belonging" (p. 162).

Perceived as a positive process which increases standards of living, heightens education, allows social-mixing and social inclusion, diversification, employment, decreasing crime rates and elevating the liveability in inner cities. However, the notion of gentrification is also perceived as a negative attribute that restrain accessibility with privatization, social injustices, leading to social segregation and isolation of lower-income inhabitants (Glass, 1964; Lees et al., 2013). The loss of local power is interpreted as a displacement factor.

Glass (1964) and Butler (2007) underlined the need to dismantle the idea of gentrification as a deindustrialisation of urban spaces or as a concept of working-class displacement. Whereas it should be interpreted as a 'mediation' between individuals and flows. Butler (2007) argued that the concept of gentrification can "elucidate some of the spatially and socially specific mediations between globalisation, the emergence of global cities and the construction of local identities" (p. 178). Furthermore, Glass (1964), pioneer of the concept, doesn't assimilate gentrification to all the transformations occurring in neighbourhoods, for her, other factors are to be accounted for the displacement of working-classes.

Through sociological debates, Butler (2007) distinguished a changing pattern linked to the sense of identity, which can be directly linked to economic, social and spatial modifications consequences. Therefore, he emphasized the need to understand the relation between people and places; "where you live became an important source of identity construction for individuals" (p. 163). Thus, his interpretation of gentrification as a concept is mainly driven by geographical and sociological aspects.

However, many scholars referred to gentrification as a process of capital flows, responding to affluent classes that unavoidable displace' indigenous populations. Cocola-Gant (2016) interpreted three different forms of displacement: the direct displacement, based on an involuntary 'out-migration'; the exclusionary displacement, which reflects the difficulties to find decent and affordable accommodations; and the displacement pressure, that is a result of a loss identity. Thus, gentrification is identified as a threat to residents 'right to stay put' (Cocola- 
Gant, 2018) and is accentuated as a violent process that dismantles the connection between 'people and place' (Elliott-Cooper et al., 2019).

In the context of displacement and populations right to stay put, many literatures assimilated gentrification to tourism, which is directly affected by changing patterns of tourism flows. Gotham (2005), Gravari-Barbas and Guinand (2017) argued that tourism plays a cultural role in the gentrification process, which in return increases development, allowing changes in businesses landscape and a wider consumption for contemporary tourism practices. Regarding gentrification' input on tourism, Cocola-Gant (2018) perceived it as a precursor to promote places. Many scholars fear that online-platforms for short-term rentals, such as Airbnb, support and facilitate the gentrification process (Wachsmuth \& Weisler, 2018). The term 'tourism gentrification' is dominant in economies that rely on tourism growth and development, providing consumption facilities and increasing visitors power to purchase. Tourism here substitutes the lack of local demand creating new opportunities for capital investments. Luring tourism through gentrification can be perceived as an ultimate solution (Gravari-Barbas \& Guinand, 2017) that eventually can become a fatal risk for cities' authenticity and uniqueness. Developed to be consumed by higher income groups, gentrified neighbourhoods can either celebrate diversity or reinforce differences (Fincher et al., 2014).

While tourism gentrification substitutes residential life with tourism, Sequera and Nofre (2018) argued that the touristifying process commodifies inner cities through the affluent growth of tourism, resulting in a dispossession of residents' material and symbolic attributes. Touristification can be linked to the impacts of gentrification; affecting the social, cultural and urban assets, which contributed to the deterioration of communities' liveability. And is attributed to the inevitable loss of residents (Jover \& Diaz-Parra, 2019). Therefore, CocolaGant $(2015,2018)$ discerned three forms of displacement related to tourism gentrification: the residential displacement, driven by tourist-oriented facilities and policies which increased with the creation of online accommodations platforms. The commercial displacement, which is based on the destruction of local businesses and the drastic changes modifying the landscapes. And the place-based displacement, referring to the loss of place due to tourism consumption of space. As a 'snow ball' effect, gentrification and tourism are driven by growth that progressively converses into a 'collective displacement' (Cocola-Gant, 2016). However, to be noted that literatures have shown that the displacement of residents is not only motivated by the incapacity to afford gentrified accommodations but by the 'loss of place'. The radical changes made to certain neighbourhoods arises cultural loss. Inasmuch, the author suggests another outcome to this phenomenon; a progressive population decrease as a result.

\section{Tourism Impacts}

In the last five years, tourism literatures and scholars have distinguished that culture has often been wrongly measured, and the consequences undergone are directed by the changes occurring inside the inner cities, which takes into consideration; touristification and overtourism, cultural identity and authenticity, gentrification and multiculturalism.

Regarding tourism impacts, Milano et al. (2019) argued that tourism growth should be identified as a generator of inequalities; rising house prices, price inflation, low access to public spaces and loss of cultural habits. To resolve these inequalities, the author highlighted the strategies been placed around capitals and affected cities to go against the 'social discomfort' felt by residents. While policies and authorities often ignore residents' quality of life, social movements are been created to address their actual situation. Taking Barcelona as an example of a city been underwater due to overtourism, he discerned the complexity of tourism developments and the repercussions which eventually can become a burden for the destination 
and its residents. Interpreting overtourism as a precursor of hostilities and a vector of weakening a destinations' attractiveness.

Furthermore, Seraphin et al. (2019) research aimed to establish a pattern between local residents and tourists in overvisited destinations. Based on the following question "How to distinguish the various archetypes of local residents with regards to their attitudes towards and relationships with visitors in destinations suffering from overtourism?" (p. 1) they focused on the negative impacts of overtourism towards locals. Through 'tourismphobia' and 'anti-tourism movements' they highlighted the deterioration and dissatisfaction held by residents leading to a certain rejection of visitors. Tourism growth is perceived as a neglection of authenticity harming culture and heritage. Associated with equity, community's quality of life and residents' sense of place attachment are weakened by the loss of cultural identity. Their research is conducted by the 'volatile attitude' of residents that is been challenged by tourism. The authors identified four categories of locals; victims, peaceful activists, vandals and resilient locals. Based on those four archetypes they underline the necessity to understand the relationship between locals and tourists to minimize the negative impacts.

While discussing the impacts of tourism, Goodwin (2017) research addressed the challenges of decline, rather the challenges of success. For instance, data on international arrivals is discerned by many scholars and authorities as a positive figure, however, the author argued that it represented an incorrect metric which doesn't reflect a destination' ability to manage tourism. Acknowledging the fact that overtourism is the antonym of sustainable development, the author highlighted the necessity for authorities to take responsibilities in order to avoid inequalities amongst residents. Consequences and their management should not be directed towards the end of tourism, but towards regulations. His paper weights up the benefits, which are driven by economy, and the costs, which are axed on cultural loss that finalizes a displacement.

Moreover, Koens et al. (2018) interpreted overtourism as a 'multidimensional and complex' issue. Caused by tourism and non-tourism stakeholders, overtourism should be analysed as a societal matter. Although tourism responded well to the economic crisis in 2008, the growing accessibility and development created an undesirable environment. Public facilities and transportations were divided among residents and visitors, which eventually lead to an overuse and to a 'visitor overkill'. Through a thorough qualitative survey among 13 different European cities, the authors axed their research on the physical and social impacts. To prevent residents' hostilities and displacements, they suggested the use of existent models, such as Carrying Capacity, in order to guide authorities towards a more responsible management.

Therefore, Dobbs and Butler (2019) argued that the concerns related to overtourism included the overconcentration of tourists in a specific area, a decline in hospitality, visitors' behaviours, cultural loss and unavoidably a diminution in residents' quality of life. Overtourism threatens destinations authenticity, which weakens directly the attractiveness. The chapter four of their book axes on the necessity and importance to preserve authenticity while developing tourism. Hence, their research focused on whether tourism should be expanded regardless of the consequences.

Which joined Anuar et al. (2019) research; focusing on the impacts of overtourism towards local communities. Through a quantitative analysis, they highlighted that tourism development gives greater positive impacts than negative ones, which communities mainly support. Nevertheless, overtourism deteriorates' the lives of host communities by modifying their social system, cultural assets and environment. Manifestations and protests are results of these inequalities amongst different social groups, driven by an excessive tourism development neglecting the role of local communities and their significance.

To enlarge the reflection, Muler Gonzalez et al. (2018) focused on the residents' perceptions of tourism as an indicator of social carrying capacity. They used it as a tool to centre discussion on the negative impacts of tourism and to highlight the limit between tourism 
benefits and its drawbacks. Although they argued that a destinations' willingness to cope with more tourism is eager by their dependence, they emphasized the necessity to utilise the concept of 'carrying capacity' to avoid a 'turning point' where tourism becomes a burden. Through a survey, they showed that the outgrowths of tourism impact' directly the perceptions, which doesn't respond to any willingness towards tourism.

Which brought authors such as Kuščer and Mihalic (2019) to monitor overtourism through a risk model. Their research was based on the existence of a responsible tourism which assess overtourism risks. By studying the residents of Ljubljana, they discerned residents' dissatisfaction and irritation that can be shown in fast-growing tourism destinations. Axed on the role of destinations to address and monitor their risk model, a noticeable disruption amongst residents and stakeholders showed a degradation in their attitudes. Therefore, their monitoring model would enable decision making towards meaningful sustainable policies and attitudes.

Meanwhile, Koens and Postma (2017) research focused on how can visitor pressure can be managed in urban tourism. Observing visitor pressure in six participating cities; Amsterdam, Barcelona, Berlin, Copenhagen, Lisbon and Munich, they were able to put forward solutions and means to overcome these pressures (65 strategies were suggested). Although their research showed that the perception of tourism differed amongst residents and communities, they also highlighted the complexity of tourism management which doesn't have a one-size-fit-all model. Interviewees were generally aware of tourism beneficial attributes, such as, economically and socially, which brought along new possibilities and opportunities. However, the negative effects remained the same; rising costs of living making life in the centre a challenge. They argued that in tourism there will always be 'winners and losers', hence the necessity for tourism management to account residents' quality of life, that will eventually meliorate visitors' experiences.

While Milano et al. (2019) gave prominence to the social movements that emerged to describe a social discontent. By studying the cases of Barcelona and Palma de Mallorca, they drew attention to the displacement phenomenon occurring between working and upper-classes. While tourism development increased economic disparities and generated inequalities, the authors added the social and cultural loss. The sense of belonging and the sense of place attachment are both been overlooked. Their research aimed to understand how destinations can sacrifice their cultural assets and inhabitants for economic purposes. Legislations and regulations are both been underlined as brutal necessities to secure local resident's well-being and visitors' search for socio-cultural connections.

\section{Methodology}

The method used in this article was divided into three sections; the first section was based on a scientific approach, that introduced the subject as a global consequence of tourism development upon touristic destinations; the second section proposed a case study providing specific examples; and the third section was directed by a qualitative analysis which provided a more profound understanding with the participants perspectives. This research approach aims to respond the following research questions:

- Can tourism be considered as a form of gentrification?

- Does tourism improve or deteriorate resident's quality of life?

- How can the cultural identity be influenced by tourism?

The use of cases studies to extend the subject was justified by what it arises; an examination of a current phenomenon and/in its real-life context, which are distinguished by Yin (1981) as two inseparable variables. Used for knowledge utilization, the approach can be 
supported by a survey, which eventually integrates the knowledge to the practice. Multiple methods can be used to study a phenomenon, which in our case, will be conducted by interviews to contextualise and for theory testing (Bhattacherjee, 2012). To extend and to bring a more accurate perspective, we selected a diversified and touristic destination that could implement our research at the fullest. Added to these characteristics, another one came along, which facilitated the interviews: the geography proximity. Therefore, with all these characteristics in mind, Lisbon was a justified case study. However, although the study could have been base on a single-case design, we deliberately conducted a multiple-case design, which reflected on several conclusions from different cases (Yin, 1981). Thus, the case study had to be narrowed down to a more precise sample of Lisbon, which resulted in the selection of several cases studies.

\section{Table 1}

Selection Criteria

\begin{tabular}{lcccccc}
\hline & Alfama & Mouraria & $\begin{array}{c}\text { Bairro } \\
\text { Alto }\end{array}$ & $\begin{array}{c}\text { Marquês } \\
\text { de Pombal }\end{array}$ & Santos & Graça \\
\hline Historical & $\mathrm{X}$ & $\mathrm{X}$ & $\mathrm{X}$ & $\mathrm{X}$ & $\mathrm{X}$ & $\mathrm{X}$ \\
Multiculturalism & $\mathrm{X}$ & $\mathrm{X}$ & $\mathrm{X}$ & - & - & $\mathrm{X}$ \\
Gentrified quarters & $\mathrm{X}$ & $\mathrm{X}$ & $\mathrm{X}$ & $\mathrm{X}$ & - & - \\
Touristic offer & $\mathrm{X}$ & $\mathrm{X}$ & $\mathrm{X}$ & $\mathrm{X}$ & $\mathrm{X}$ & $\mathrm{X}$ \\
Touristic demand & $\mathrm{X}$ & $\mathrm{X}$ & $\mathrm{X}$ & $\mathrm{X}$ & $\mathrm{X}$ & $\mathrm{X}$ \\
Tourism visible impacts & $\mathrm{X}$ & $\mathrm{X}$ & $\mathrm{X}$ & - & - & - \\
Airbnbisation & $\mathrm{X}$ & - & $\mathrm{X}$ & $\mathrm{X}$ & - & - \\
\hline
\end{tabular}

The criterions were elaborated based on the research objectives, but mainly from the literatures available and observations. The narrowed down neighbourhoods were Alfama, Mouraria and Bairro Alto, which responded to certain essential criterions: historical parts of the downtown; culturally diversified; touristic hot spots; manifestations of residents' discontentment, and eventually for their geographical location, their historical backgrounds, their heritage, their diversity, and their active participation in Lisbon' tourism growth.

\section{Figure 1}

Lisbon historic centre and its different neighbourhoods, Source: Grondeau and Pondaven (2018) p.6 (adjusted from original).

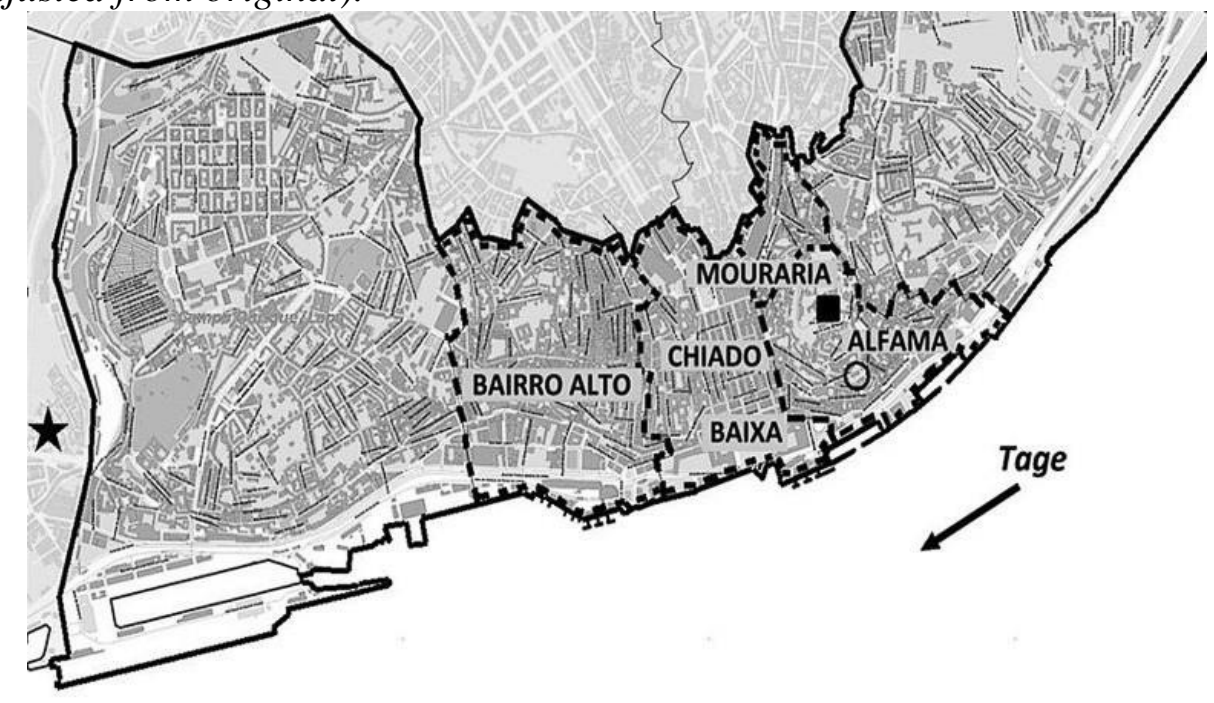

Note. "Le Street Art, Outil de Valorisation Territoriale et Touristique : L'exemple de Galeria Arte Urbana de Lisbonne." by A. Grondeau and F. Pondaven, 2018, EchoGeo, (44) (https://doi.org/10.4000/echogeo.15324). 
First, to support our cases studies and to answer the objectives of the research, a qualitative analysis was elaborated, permitting an understanding of participants perspectives through a direct participation in their lives. Bhattacherjee (2012) argued that "the emphasis in qualitative analysis is sense making or understanding a phenomenon, rather than predicting or explaining" (p. 113). Focusing on participants observations, our pre-existing understandings can then be modified towards new theories. However, theories aren't absolute rules or laws, they discern social behaviours and thus shape individuals' observations (Ezzy, 2002). To support "participants' views, feelings, intentions, and actions as well as the contexts and structures of their lives" (Charmaz, 2006, p. 13) the collection of "rich data' becomes then a necessity. Which eventually allows the researchers to enter into participants lives from the inside towards other perspectives and to follow leads during the course of the interviews.

Secondly, to support a certain liberty in the participants responses, the interviews were conducted as 'open-ended' interviews, which were elaborated through open-ended questions that enlarged preconceived codes or received ideas that the interviewer may have (Charmaz, 2006). Implementing the notion of respect towards our participants allowed to focus more on their perspectives, leaving our own assumptions out. To be noted that respecting and understanding doesn't mean that the interviewer agreed with an individual's perspectives, but that he was able to consider another point of view. The interviewer is non the less an observer that can eventually encourage a person' response through the requirement of more details, focusing on significant statements and observations (Charmaz, 2006).

Finally, although the use of IT-supported strategies is enthusiast by researchers, the qualitative data analysis conducted used manual methods, based on the same research goals of software programs; "analysing the differences, similarities and relationships between passages of text and the development of typologies and theories" (Flick et al., 2004, p. 278). It incorporated the construction of indexes and the use of cross-references. Although is it highlighted as a more time-consuming exercise, the choice was based on the shortness of the interviews conducted and the similar patterns used by the participants to answer the survey' questions.

To finalize our research on whether tourism development impacts the cultural identity of the selected neighbourhoods, we defined two open-ended questions:

- What are the elements of your neighbourhood cultural identity?

- What are the impacts related to tourism growth within your neighbourhood?

The questions would enlarge our pre-existing understandings and knowledge, procuring the research an insight on participants lives and observations. The choice of these questions was motivated by our objectives; to understand the dimensions of tourism development; understand the repercussions of tourism development upon communities; distinguish the actors within touristic destinations; understand how tourism growth is a direct actor upon cultural identity loss.

\section{Instruments and Participants' Sample}

The open-ended questions were determinant to integrate and consider the three different neighbourhoods selected. Despite the attempt to reach a certain balance between the participants, several factors modified our first approach; language differences and potential annoyance from certain participants, that directed our interviews towards other notions; time and interest. Furthermore, the interviews weren't randomly established in the streets, but were conducted in familiar places such as local restaurants, cafés, bars and local shops. This process was elaborated during the first attempts to interview individuals in the streets and was felt as a 
Daly, P.

genuine non-interest that could be justified with the common "street interviews", and can be perceived as 'annoying' and 'repetitious'.

The selection of interviewees was based on one principal criterion: to be a resident of the interviewed neighbourhood. The participants nationality, gender, age or profession weren't perceived as essential qualifications for participation, and weren't identified as an outweigh for the research. However, for contextualisation and interpretation purposes, we elaborated a sample of the characteristics of the participants. To be noted that the implication of residents, immigrants and new gentrifiers was highlighted as essential to obtain different point of views and observations, therefore, the selection of interviewees was unconsciously guided by a diversification of respondents.

Finally, during the realisation of the interviews, conducted first in Bairro Alto for proximity reasons, we reached the data saturation point while conduction the thirteenth interview; responses were becoming redundant. Therefore, to establish a balance between the data collection, we followed the same amount in each interviewed neighbourhood: 90 interviews were conducted, divided equitably within the interested neighbourhoods.

Table 2

Sample Description

\begin{tabular}{lcccc}
\hline & Alfama & Mouraria & Bairro Alto & Total \\
Participants & $\mathbf{3 0}$ & $\mathbf{3 0}$ & $\mathbf{3 0}$ & $\mathbf{9 0 / \%}$ \\
\hline Gender & & & & \\
\hline Feminine & 20 & 16 & 23 & $\mathbf{5 9}(\mathbf{6 6 \%})$ \\
Masculine & 10 & 14 & 7 & $\mathbf{3 1}(\mathbf{3 4 \%})$ \\
\hline Age & & & & \\
\hline $20-40$ & 11 & 20 & 14 & $\mathbf{4 5}(\mathbf{5 0 \%})$ \\
$40-60+$ & 19 & 10 & 16 & $\mathbf{4 5}(\mathbf{5 0 \%})$ \\
\hline Nationality & & & & \\
\hline Portuguese & 21 & 13 & 17 & $\mathbf{5 1 ( 5 7 \% )}$ \\
International & 9 & 17 & 13 & $\mathbf{3 9 ( 4 3 \% )}$ \\
\hline Professions & & & & \\
\hline Related to tourism & 22 & 18 & 3 & $\mathbf{6 1 ( 6 8 \% )}$ \\
$\begin{array}{l}\text { Not related to } \\
\text { tourism }\end{array}$ & - & 7 & 6 & $\mathbf{1 9}(\mathbf{2 1 \%} \%)$ \\
Retired & 8 & 5 & & \\
\hline
\end{tabular}

The table 2 represents the analysis of the participants characteristics. Despite the attempt to have an equitable balance between the respondents, the majority of the participants were feminine, $66 \%$ of them in contrast to $34 \%$ of masculine participants. A genuine participation of feminine participants was observed in all three interested neighbourhoods and is interpreted as a 'gender facility' regarding the gender of the interviewer. However, to have a certain variety between the interviewees, $50 \%$ of them were under the age of 40 and $50 \%$ were above the age of 40 . Out of the participants interviewed, $39 \%$ were over 55 years and $22 \%$ of them were born and raised in their neighbourhood, opposed to $55 \%$ were living in their neighbourhood from an inferior period of 15 years. Furthermore, $57 \%$ of the respondents were Portuguese and $43 \%$ were immigrants living in Lisbon since the last 15 years (Asian, Brazilian, Mexican, Chilean and French). Added to these characteristics, we asked the respondents if their professions were related to tourism, which gave prominence to the fact that these neighbourhoods are not only touristic spots but their local economy is supported by tourism: $68 \%$ of the participants were active participants in tourism through hospitality, catering and accommodation. 
Moreover, the interviews highlighted other notions, that aren't quantified but discerned as essential notions for further understandings: time and language. On one hand, the notion of time was a determinant factor for the selection of participants; which defined the participants willingness and interest. At the first stage of interviews, we were faced to constate that residents weren't only reluctant to physical interviews or to been asked randomly, they were also afraid of the interviews been 'time consuming'. Therefore, despite our method used based on Charmaz (2006) concept; "intensive interviews can allow an interviewer to: go beneath the surface of the described experience(s); stop to explore a statement or topic; request more detail or explanation; ask about the participant's thoughts, feelings, and actions; keep the participant on the subject; (...) slow or quicken the pace; shift the immediate topic; (..) use observational and social skills to further the discussion; respect the participant and express appreciation for participating" (p.24) we were 'forced' to conduct directed conversations as minimalistic possible. However, when the interviewer responded to the subject, we were then able to implement fully our interviews and more. The interviews lasted between 5 to 25 minutes, with a noticeable time difference between the participants that lived the growth of tourism (namely the ones living in a given neighbourhood before the crisis of 2008) and the ones that arrived with and because of tourism development.

On a second hand, the notion of language was also determinant during several interviews. Despite the fact that the immigrants interviewed were mostly living in Lisbon for the last 3 to 15 years, we noticed a certain difficulty to understand fully the observations made by some. Especially in the neighbourhood of Mouraria, were multiculturalism is predominant (Gurer, 2019; LaPaglia, 2018), some of the interviews had to be conducted in English and sometimes by translation from an external participant. Therefore, the participation of residents (all confused) into the discussion as a source of data and as co-researchers can be discussed as valuable or endangering the data analysis process (Ezzy, 2002).

\section{Results and Discussions}

The data collection and analysis were leaded manually with a process of registers and cross-references (Flick et al., 2004). Both methods were used to extract similarities between the observations of the participants; words used and personal histories. Qualifying the words facilitated the time-consuming exercise that involved manual method; organizing textual passages and their significances. Added to this approach, we used Bhattacherjee (2012) figure mentioned below to visually contextualize the data collected towards analysis.

\section{Figure 2}

The Existential Phenomenological Research Method, source: Bhattacherjee (2012) p.109.

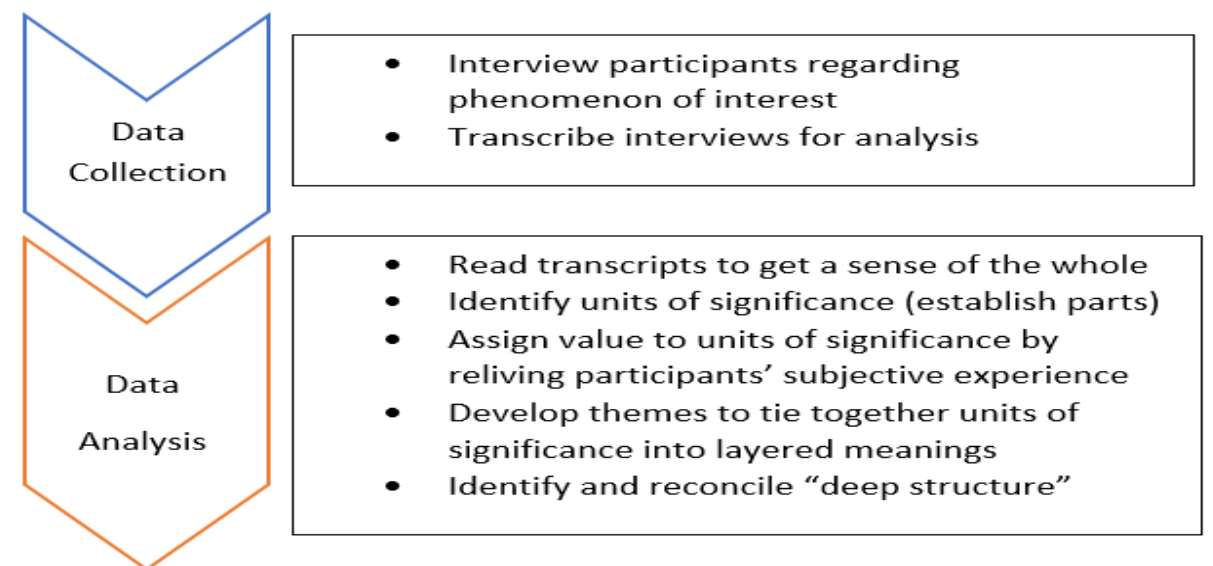


Note. "Social Science Research: Principles, Methods, and Practices," by A. Bhattacherjee, 2012, Textbooks Collection. Scholar Commons.

The results of the qualitative analysis were identified into two main topics: the cultural identity of the selected neighbourhoods and the main impacts of tourism growth within these neighbourhoods. Tables 3 and 4 provides information on the frequencies and percentages identified by the residents during the data analysis of the interviews.

Table 3

Cultural Identity Contents Identified in the Interviews (Frequencies and Percentages)

\begin{tabular}{|c|c|c|c|c|}
\hline & Alfama & Mouraria & Bairro Alto & Total \\
\hline \multicolumn{5}{|l|}{ Urban structure } \\
\hline Architecture & $18(60 \%)$ & - & $22(73 \%)$ & 40 \\
\hline Authenticity & $23(77 \%)$ & $12(40 \%)$ & $28(93 \%)$ & 63 \\
\hline Public spaces & - & $13(43 \%)$ & $12(40 \%)$ & 25 \\
\hline Miradors & $24(80 \%)$ & $19(63 \%)$ & $20(67 \%)$ & 63 \\
\hline Castle Sao Jorge & - & $20(67 \%)$ & - & 20 \\
\hline Traditional & $21(70 \%)$ & $11(37 \%)$ & $22(73 \%)$ & 54 \\
\hline Local retailers/facilities & $4(13 \%)$ & $9(30 \%)$ & $7(23 \%)$ & 20 \\
\hline \multicolumn{5}{|l|}{ Social } \\
\hline Life in the neighbourhood & $24(80 \%)$ & $24(80 \%)$ & $26(87 \%)$ & 74 \\
\hline Social networks & $11(37 \%)$ & $17(57 \%)$ & $13(43 \%)$ & 41 \\
\hline Local residents & $14(47 \%)$ & $9(30 \%)$ & $11(37 \%)$ & 34 \\
\hline Local housings & $8(26 \%)$ & - & $10(33 \%)$ & 18 \\
\hline Socio-cultural attributes & $12(40 \%)$ & $11(37 \%)$ & $15(50 \%)$ & 38 \\
\hline Social authenticity & $15(50 \%)$ & $7(23 \%)$ & $18(60 \%)$ & 40 \\
\hline Perception of security & $13(43 \%)$ & - & $3(10 \%)$ & 16 \\
\hline Perception of insecurity & $6(20 \%)$ & $19(63 \%)$ & $23(77 \%)$ & 48 \\
\hline Perception of drogues/alcohol & - & $25(83 \%)$ & $21(70 \%)$ & 46 \\
\hline \multicolumn{5}{|l|}{ Authentic characters } \\
\hline Artistic & $9(30 \%)$ & $14(47 \%)$ & $17(57 \%)$ & 40 \\
\hline Festivities & $27(90 \%)$ & $25(83 \%)$ & $29(97 \%)$ & 81 \\
\hline 'Santos Populares' & $30(100 \%)$ & $23(77 \%)$ & $30(100 \%)$ & 83 \\
\hline Fado & $30(100 \%)$ & $22(73 \%)$ & $18(60 \%)$ & 70 \\
\hline Tascas/gastronomic & $30(100 \%)$ & $25(83 \%)$ & $25(83 \%)$ & 80 \\
\hline Multicultural & $5(17 \%)$ & $30(100 \%)$ & $11(37 \%)$ & 46 \\
\hline \multicolumn{5}{|l|}{ Tourism attributes } \\
\hline Touristic place & $30(100 \%)$ & $17(57 \%)$ & $30(100 \%)$ & 77 \\
\hline Cohabitation(residents/tourists) & $8(27 \%)$ & $15(50 \%)$ & $7(23 \%)$ & 30 \\
\hline \multicolumn{5}{|l|}{ Total of answers } \\
\hline & 362 & 367 & 418 & 1147 \\
\hline Number of subjects & 30 & 30 & 30 & 90 \\
\hline Mean (answers/subject) & 12.1 & 12.2 & 13.9 & - \\
\hline
\end{tabular}


Table 4

Impacts of Tourism on Historical Neighbourhoods In Lisbon, Perceived by Residents.

\begin{tabular}{|c|c|c|c|c|}
\hline Tourism impacts & Alfama & Mouraria & Bairro Alto & Total \\
\hline \multicolumn{5}{|l|}{ No impact } \\
\hline $\begin{array}{l}\text { Tourism growth is not a } \\
\text { problem }\end{array}$ & $3(10 \%)$ & - & - & 3 \\
\hline \multicolumn{5}{|l|}{ Environmental } \\
\hline Pollution & $9(30 \%)$ & $19(63 \%)$ & $15(50 \%)$ & 43 \\
\hline Noise & $17(57 \%)$ & $9(30 \%)$ & $23(77 \%)$ & 49 \\
\hline Transits & $19(63 \%)$ & $10(33 \%)$ & $15(50 \%)$ & 44 \\
\hline $\begin{array}{l}\text { Carrying capacity } \\
\text { (overcrowded) }\end{array}$ & $25(83 \%)$ & $10(33 \%)$ & $23(77 \%)$ & 58 \\
\hline \multicolumn{5}{|l|}{ Economic } \\
\hline $\begin{array}{l}\text { Rehabilitation of buildings for } \\
\text { touristic use } \\
\text { (accommodations) }\end{array}$ & $29(97 \%)$ & $15(50 \%)$ & $29(97 \%)$ & 73 \\
\hline Rehabilitation of public spaces & $14(47 \%)$ & $17(57 \%)$ & $19(63 \%)$ & 50 \\
\hline Privatisation of public spaces & $7(23 \%)$ & $10(33 \%)$ & $16(53 \%)$ & 33 \\
\hline $\begin{array}{l}\text { Disappearance of traditional } \\
\text { local shops }\end{array}$ & $28(93 \%)$ & - & $27(90 \%)$ & 55 \\
\hline \multicolumn{5}{|l|}{ Socio-cultural } \\
\hline Higher housing/retail rents & $30(100 \%)$ & $15(50 \%)$ & $28(93 \%)$ & 73 \\
\hline Airbnb and Hotels & $29(97 \%)$ & $16(53 \%)$ & $30(100 \%)$ & 75 \\
\hline Degradation of buildings & $12(40 \%)$ & $8(27 \%)$ & $8(27 \%)$ & 28 \\
\hline Dislocation of inhabitants & $27(90 \%)$ & $17(57 \%)$ & $29(97 \%)$ & 73 \\
\hline Insecurity & - & $15(50 \%)$ & $17(57 \%)$ & 32 \\
\hline Loss of neighbourhood life & $17(57 \%)$ & $10(33 \%)$ & $20(67 \%)$ & 47 \\
\hline Loss of identity & $19(63 \%)$ & $10(33 \%)$ & $18(60 \%)$ & 47 \\
\hline Loss of traditions & $19(63 \%)$ & $10(33 \%)$ & $17(57 \%)$ & 46 \\
\hline \multicolumn{5}{|l|}{ Total of Answers } \\
\hline & 304 & 191 & 334 & 829 \\
\hline
\end{tabular}

\section{Cultural Identity Contents}

While discussing the perceived cultural identity attributes of each neighbourhoods, four categories were distinguished; urban structure, social, authentic characters and tourism attributes. Concerning the urban structure contents, the participants of Alfama and Bairro Alto valued similar cultural structures that identified their neighbourhood as authentic and traditional. The narrow streets, the miradors, the colins, the electric elevators, the stairs, and the cultural costumes such as the drying clothes hanging from balconies, were identified as main characteristics of their picturesque neighbourhood. Alfama valorised the miradors $(80 \%$ of the respondents) as 'pictures' representing the neighbourhood, and Bairro Alto highlighted the unavoidable stair cases as a representation of the neighbourhood' soul. Meanwhile, as the neighbourhood of Mouraria takes into account distinctive parts; the higher part which is characterised as more 'traditional' and the lower part interpreted as 'multicultural', the responses were mitigated. However, a common attribute to the three neighbourhoods was the lack of local retailers; participants discerned it as a 'vanishing' authentic attribute.

In terms of social contents, the living life in the neighbourhoods is perceived as a fundamental element of their culture. Participants highlighted the cultural habits of their daily 
lives, such as the unavoidable image of elderly people talking from their balcony to their neighbours, families in the streets, children playing, elderly people on public benches, with the sound of the television behind opened doors, fado playing at high volume, while the barbecues are been heated during summer and cold beers are been served. These postcard images are what the participants defined as their social life within their neighbourhoods. However, the participants were all concerned about the future: through gentrification and rehabilitation programs, many saw their neighbours and friends forced to move out of the neighbourhood. Participants only mentioned locals or locals' housings to underline the threat made to their neighbourhoods; although local residents remain in the neighbourhoods, the slow expulsion that threatens them is a direct risk to the neighbourhood' social authenticity. Meanwhile, the perception of security was low or non-existent, the perception of insecurity in Mouraria (63\% of the respondents) and Bairro Alto (77\% of the respondents) was directly put forward by the residents as the main negative attribute of their neighbourhood quality of life, taking into consideration drogues and alcohol use (83\% of the respondents in Mouraria and $70 \%$ in Bairro Alto).

The government' programs to rehabilitate Alfama were life changers; the buildings were falling apart and the living conditions were deteriorating. However, we didn't think about the consequences. Our neighbourhood was suddenly more attractive for higher-classes and became a certain attraction over the years, neglecting its original residents that made the neighbourhood authentic. My parents used to pay, 20 years ago, 10euros per month to rent their house, imagine what you can do with 10euros nowadays? Nothing. (Isabel, 62 years, born and raised in Alfama.)

Regarding the authentic characters, Alfama, Bairro Alto and Mouraria made unanimity concerning the festivities and the joys that it engenders. Participants qualified their neighbourhoods as happy places, where festivities, such as Santos Populares, were 'unmissable' events that would celebrate their values, believes and roots. The authenticity is also discerned through their immaterial heritage; Fado, which reunites neighbours together and contribute to their cultural identity. Furthermore, coined as artistic neighbourhoods, Bairro Alto (37\% of the respondents) and Mouraria (100\% of the respondents) are both discerned as multicultural and diversified neighbourhoods. Diversified in their own ways; Bairro Alto is identified as the 'bohemian' Lisbon, that welcomes all artistic souls and bohemian lifestyles seekers. And Mouraria as a celebration of multiculturalism and exoticism; the neighbourhood where minorities and ethnic communities can find a 'home'.

Concerning tourism attributes, the participants were conscious of their neighbourhood' touristic influence, which modified their daily lives, mainly through the 'forced' cohabitation with tourists and visitors. However, the participants of the lower part of Mouraria, shown no concern towards the cohabitation with tourists, their rootedness of been mainly immigrants their selves can explain the feeling of been non-threated by this cohabitation (explained one of the interviewees).

\section{Impacts Related to Tourism Growth}

The identified responses concerning impacts of tourism growth were grouped into three domains; environmental, economic and socio-cultural (based on Bernardo et al., 2016). Marked by residents' perceptions, the neighbourhood's concerns conducted a similar pattern. The environmental category highlighted four main impacts; pollution, noise, transits and overcrowding. Interviews shown that Alfama residents were concerned about the transits (63\% of the respondents) due to touristic routes and attractions that features the popularisation of tuk- 
tuks tours and the overcrowded public areas (83\% of the respondents) that diminished their accessibility. Whereas, Bairro Alto participants highlighted noise disturbances $(83 \%$ of the respondents) as the major drawback of their neighborhood quality of life. They call it the "noise pollution' motivated by rudeness and un-respectful tourists. This finding confirms Pavel' (2016) perception of noise as a major drawback of touristified neighbourhoods. Moreover, concerning pollution, the participants were all conscious that littering was long before the arrival of tourism a common problem, however, they point out that it has been amplified with tourism, especially in Mouraria and Bairro Alto.

In terms of economic impacts, the interviewees discerned seven impacts; rehabilitation of building for touristic use, rehabilitation of public space, privatization of public spaces, disappearance of traditional local shops, higher housing/retail rents, Airbnb and hotels, and employment. Many residents' participants were conscious about economic benefits; employment constitute the main positive impact that all three neighbourhoods discerned as important, followed by the rehabilitation of public spaces towards the bonification of outdoors. However, the rehabilitation of public spaces was also identified as the mean to privatise public spaces; for instance, the mirador of Santa Catarina was once privatised by the Verride Palácio de Santa Catarina, a five stars hotel. Although the rehabilitations of buildings were perceived as an economic contribution to the neighbourhoods, the rehabilitations of buildings into accommodations for touristic use is been revendicated as a neglection of locals. The Airbnbisation of touristified neighbourhoods, the increase of housings and retail rents, and the disappearance of traditional local shops are major impacts in Alfama (93\% of the respondents) and in Bairro Alto (90\% of the respondents). Once again, a certain difference was noticed between the residents of Mouraria; the lower part valued tourism as a source of employment (77\% of the respondents) and the higher part were well aware of the airbnbisation of their streets, pointing them out like if it was normal. Thus, the confirmation and contribution to scholars' literatures by observing a more prominent deterioration of their living habits, conditions and accessibilities (Cocola-Gant, 2015; Krase, 2012; Pizam, 1978).

Concerning socio-cultural impacts, residents identified six main impacts; degradation of building, dislocation of inhabitant, insecurity, loss of neighbourhood life, loss of identity and loss of traditions. Although the degradation of buildings wasn't pointed out as a direct consequence of tourism, it was highlighted as a consequence of overuse. And despite our preexisting understandings, insecurity was long felt in certain neighbourhoods, long before the arrival of tourism, which in time amplified it. Nonetheless, this notion of insecurity is neglected by authors as not been directly linked to tourism, the assimilation of insecurity to tourism can be interpreted as future debate. Furthermore, Mouraria (50\% of the respondents) and Bairro Alto (57\% of the respondents) interviewees considered their proper quarter as dangerous places to adventure by night and pointed out certain streets as 'problems'.

Finally, when asked the question "What are the impacts related to tourism growth within your neighbourhood?" a general response was the dislocation of inhabitants $(90 \%$ of the respondents in Alfama, 57\% in Mouraria and 97\% in Bairro Alto). A dislocation that is conducted by all impacts mentioned above and driven by the loss of their neighbourhood life, traditions and finally the loss of their identity. Although this finding concords with many scholars' literature (Barata-Salgueiro et al., 2017; Cruz Lopes et al., 2019; Sequera \& Nofre, 2018, 2019), it is mostly highlighted as the consequence of gentrification, that is eventually emphasised by tourism gentrification and touristification (Butler, 2007; Cocola-Gant, 2016, 2018; Glass, 1964; Gotham, 2005; 2018; Milano et. al, 2019; Sequera \& Nofre, 2018).

I don't recognize my own neighbourhood. Everything was cloned to attract and seduce tourists. Local shops have closed to open postcards shops, bars or even fancy restaurants serving 'Portuguese food' which 
are majorly owned by foreigners. Recently I've discovered a 'cereal bar'?! Have you ever seen a Portuguese go inside? Me neither. What makes me sad, is that tourism doesn't respect the cultural characters of the neighbourhood, it only sees the potential economic benefit. (Rita, 45 years, local shop owner in Bairro Alto.)

\section{Illustrated Results}

By sampling the most valuable data identified by the participants, a certain pattern between residents' interpretations was perceived and illustrated:

\section{Figure 3}

Illustrated Results
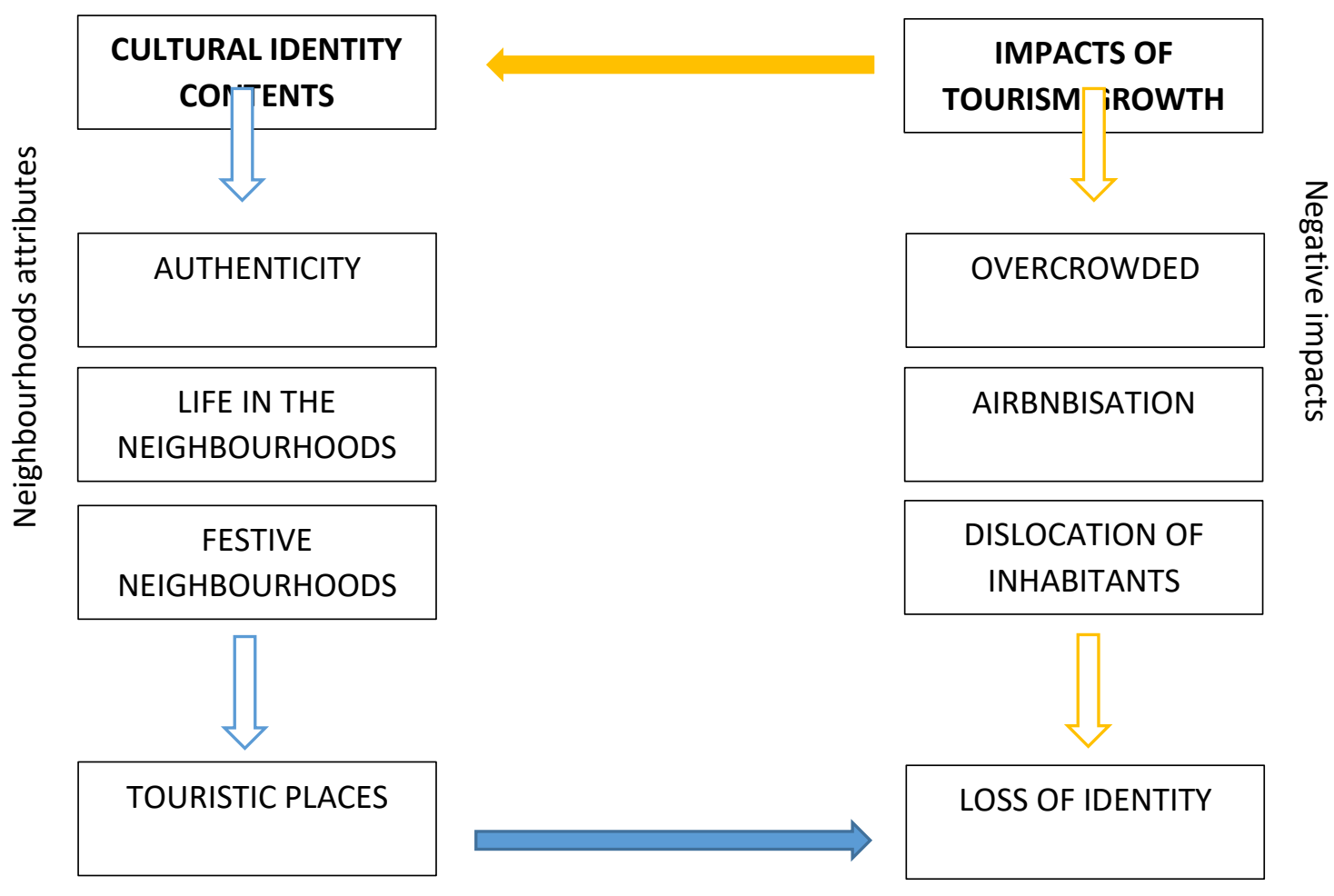

\section{Conclusions}

\section{Theoretical Considerations}

Gentrification was long considered as the 'embourgeoisement' of a city through the social geography (Mendes, 2013), however, gentrification also takes into account the physical transformations through urban rehabilitation (Cruz Lopes et al., 2019). In other words, rehabilitation generated gentrification; with the same characteristics, rehabilitation improved the spatial environment allowing economic plus values. And eventually led to the same conclusions; the inclusion of affluent social classes and the exclusion of lower-classes; a social re-composition.

Urban rehabilitation processes supposed the restoration of the built environment, not the destruction by replacement, which led to a refinement of a city's social image and housing quality, resulting in a certain 'upgrade' of the neighbourhoods (Mendes, 2013). However, urban rehabilitation provoked changes within the social geography and accentuate the gentrification process as a 'social filter'. While social re-composition enhanced social substitution, Mendes 
(2013) marked the pattern between the process and the socio-spatial segregation that intensified the social division and exclusion amongst different income classes.

Scholars have highlighted that the effects of tourism resembled those caused by gentrification (Barata-Salgueiro et al., 2017). And Pavel (2016) argued that "the processes of gentrification and touristification are key actors in the proliferation of spaces of cultural and economic segregation" (p. 1) which eventually reflects of the urban cultural and economic issues within historic cities. In addition to this challenge, the growth of touristified cities have constructed them into mass tourism phenomenon. The author argued that such transformations developed 'stereotypical images' of what cities should become to attract international markets. Touristification is been compared to an "aggressive form of urban accumulation by dispossession and spatial displacement against the working and middle-lower classes of the "tourist city"' (Sequera \& Nofre, 2019, p. 1). Assimilated to the gentrification process, touristification grow the airbnbisation process.

Moreover, considered as a precursor for tourism growth, globalisation generated exclusions through the development of space consumption; the commodification of the traditional environment into leisure and tourist-oriented markets, resulting in the 'exodus' of the local population (Pavel, 2016). Which added to this, tourism development redefined historic cities centres as cultural objects dedicated to consumption (Cruz Lopes et al., 2019). Touristoriented attractions and accommodations, driven by economic gain, eventually replaced the 'free' public spaces into compulsory consumer spaces (Barata-Salgueiro et al., 2017).

Marketing strategies towards tourism development and the creation of tourist-oriented attractions developed 'disneyficated' areas; by emptying historical neighbourhoods of its local residents, touristified neighbourhoods responded to: "the tourist only meets other tourists" (Pavel, 2016, p. 9), which unavoidably compromises the social cohesion. Culture and tourism are been used for economic reasons and strategies; touristification gained political dimensions, reinforcing a destination' competitiveness and attractiveness (Sequera \& Nofre, 2019).

Finally, the eventual conflict between residents and tourists towards a preservation of heritage opposes' tourism development to a deterioration of place attachment and quality of life (Bernardo et al., 2016). While there is a noticeable conflict between the preservation of a place' identity and tourism growth, scholars concluded that the social restructuration of a neighbourhood unavoidably damages the place' identity. By dispossession and cultural transformations, a community's socio-cultural attributes are been seriously damaged and affected by tourism development. Not only that tourism deteriorated residents' quality of life, tourism neglected the residents' role in tourism development; as a necessity (Castela, 2018; Sequera \& Nofre, 2019).

\section{Practical Considerations}

The study of Lisbon' historical neighbourhoods, Alfama, Mouraria and Bairro Alto, confronted our pre-existing understandings on tourism growth to the impacts generated on cultural identity. Identity that can be distinguished into four different forms; urban structure, environmental, individual and social. The urban structure refers to the physical characteristics that ascertain a place identity, and the individual and social categories refers to the resident's rootedness and emotions which allow social identity (Bernardo et al., 2016).

By modifying the urban structure through processes of revitalisation and rehabilitation, local governments improved the physical aspects of the neighbourhoods, which responded to an urgent deterioration of living conditions in Lisbon' downtown. However, the modification and promotion of cultural assets, historical and architectural symbols commodified the social aspects of the neighbourhoods. Through rehabilitation, Alfama and Bairro Alto, regained their once lost attractiveness and gained economic strength but at what cost? The embellishment and 
'embourgeoisement' through rehabilitation and gentrification processes neglected their cultural authenticity (Bernardo et al., 2016). Gentrification that was encouraged and driven by rehabilitation eventually provoked the touristification process of Lisbon historical neighbourhoods.

Policies towards rehabilitation were physical and social. Physical towards the rehabilitation of urban structures and social towards residents' well-being, by meliorating a neighbourhood' image and living conditions. For instance, the earthquake of 1755 depopulated numerous neighbourhoods of Lisbon' down town, leaving lower-income groups in 'abandoned' neighbourhoods. Rehabilitation and revitalisation were social manifestations to regain inhabitants and attractiveness. However, local associations and citizens, in Bairro Alto, Alfama and Mouraria, opposed their selves to these processes of rehabilitation and gentrification, which neglected their right to remain in their neighbourhood and be contributors to the cultural identity (Pavel, 2016).

Individual and social perceptions of identity are challenged by transformed/modified neighbourhoods. For instance, Mouraria is categorised as a place that 'breaths' what it means to be part of a multicultural historical neighbourhood, but is threated by growing gentrification that prominence exclusion rather than inclusion. The residents' sense of place attachment and place identity is constantly been disrupted by the growth of tourism, dominated by tourism gentrification. Certain neighbourhoods are currently dominated by tourism; Alfama figures as a 'touristscape' suggesting that the influence of tourism gentrification and commercial gentrification outgrow the local community (Sequera \& Nofre, 2019).

Eventually, although tourism development and gentrification are discerned by residents as economic benefits non-negligible for their neighbourhoods, through employment and opportunities, their main concern is to know when it will stop; before arriving to the stage of non-retour. For instance, Alfama' residents that participated in the survey, felt that the use of cultural heritage in marketing strategies was non the less a process of 'selling places' rather than supporting local communities. Also perceived in Mouraria, with the touristic routes around Fado, compromising what was once a source of gathering and conviviality into a product created by tourism and consumed by tourists (Fuarros, 2016). And finally, Bairro Alto' image of the nightlife of Lisbon, created hostilities amongst residents and tourists towards a complicated cohabitation; highly supported by the airbnbisation of the neighbourhood and the non-respect of local resident's well-being. Finally, residents' have commonly pointed out the negligence of tourism development planners and policies, that have yet established strategies or policies to minimise the impacts on local communities.

\section{Limitations and Future Investigations}

Throughout this investigation, certain limits have emerged during the realisation of the qualitative analysis. First, the choice of using certain neighbourhoods instead of others were justified but questioned and doubted during the phase of interviews; especially the case of Mouraria. Mouraria' is a rather complex neighbourhood, that regroups not only distinctives cultures and identities but also distinctives parts of the neighbourhood. Mouraria can be divided into three different parts; the lower part marked by economic activities, the centre part marked by housing and the rest marked by illegal activities and homelessness (Corte-Real, 2016). Highlighted as the most multicultural neighbourhood of Lisbon, we were faced with language differences that lead to think that using the participation of residents 'all-confused' into the discussion as a source of data could have falser the data analysis (Ezzy, 2002).

Secondly, but not least, conducting the interviews during the pandemic of Covid-19 made residents more resilient to participation, which limited the participation of elder individuals. To remediate to this 'unexpected' limit, we lowered our expectations in terms of participants, and focussed on a 'qualitative' number of subjects. Therefore, it should be noted 
that this study is limited, due to a reduced sample size and is not representative of the neighbourhoods, especially Mouraria.

Thirdly, the cases studies have distinguished major contributors to spatial and cultural transformations, that weren't directly linked to tourism. Future investigations should open discussion on policies interventions and contributions to cultural identity loss. Ezzy (2002) approach argued that "the different ways in which qualitative research can be relevant to the policy process, and then moves to an examination of how published research has actually influenced, or failed to influence, public policy" (p. xv). Which could highlight furthermore the negligence from tourism development planners and policies to take into account the importance and vital role of local actors (Bernardo et al., 2016); discerned as potential losses, authenticity and uniqueness should be further studied in terms of comprehension.

Finally, although this study focused on Lisbon' historical neighbourhoods, we perceived similarities with other touristic destinations; tourism-oriented impacts can be encountered in any touristic destination that suffers from a loss of cultural identity. All the impacts mentioned and highlighted above are actual threats that endangered Barcelona, Venice, Amsterdam and other European touristic hot-spots (Seraphin et al., 2019). However, these issues aren't specific to this side of the world, many cities and historical spaces are been slowly or actively destroyed by tourism. For instance, Machu Picchu (Baumhackl, 2019) and Maya Bay (Koh \& Fakfare, 2019) are constantly put in jeopardy by tourism flows and had to take drastic measures; to close the sites while nature recuperates and residents of cities nearby to eventually 'breath'.

\section{References}

Andereck, K., Valentine, K., Knopf, R., \& Vogt, C. (2005). Residents' perceptions of community tourism impacts. Annals of Tourism Research, 32(4), 1056-1076. https://doi.org/10.1016/j.annals.2005.03.001

Andriyani, AAD , Djatmika, Sumarlam \& Rahayu, E.T. (2019). Learning from FaceThreatening Acts by Tourism Workers in Bali: The Impacts of Cross-Cultural Misunderstanding. Journal of Social Studies Education Research, 10(3), 64-81. Retrieved from https://jsser.org/index.php/jsser/article/view/1053/387

Anuar, A., Ridzuan, F., Jaini, N., Sulaiman, F., \& Hashim, I. (2019). The impact of overtourism towards local community in Heritage City. Journal of Tourism \& Hospitality, 8(3), 15. https://doi.org/10.35248/2167-0269.19.8.406

Barata-Salguiero, T., Mendes, L., \& Guimaraes, P. (2017). Tourism and urban changes Lessons from Lisbon. In M. Gravari-Barbas \& S. Guinand, Tourism and gentrification in contemporary metropolises (pp. 255-270). Routledge.

Baumhackl, H. (2019). Peru "Land of the Incas". A tourism destination on the rise. Tourism \& Hospitality Management, 7(2), 95-116. https://doi.org/10.15640/jthm.v7n2a10

Beckett, G. H., \& Kobayashi, M. (2020). A Meta-study of an Ethnographic Research in a Multicultural and Multilingual Community: Negotiations, Resources, and Dilemmas. American Journal of Qualitative Research, 4(1), 85106. https://doi.org/10.29333/ajqr/8267

Belabas, W., Eshuis, J., \& Scholten, P. (2020). Re-imagining the city: Branding migrationrelated diversity. European Planning Studies, 28(7), 1315-1332. https://doi.org/10.1080/09654313.2019.1701290

Bernardo, F., Almeida, J., \& Martins, C. (2016). Urban identity and tourism: Different looks, one single place [Proceedings]. Institution of Civil Engineers. Urban Design \& Planning, 170(5), 205-216. https://doi.org/10.1680/jurdp.15.00036

Bhattacherjee, A. (2012). Social science research: Principles, methods, and practices. Textbooks Collection. . 
Butler, T. (2007). For gentrification? Environment \& Planning A, 39(1), 162-181. https://doi.org/10.1068/a38472

Carothers, D. (2018). A culture of equality?. Journal of Culture and Values in Education, 1(2), 42-57. https://doi.org/10.46303/jcve.01.02.3

Castela, A. (2018). Impacts of tourism in an urban community: The case of Alfama. Athens Journal of Tourism. 5(2), 133-148. https://doi.org/10.30958/ajt.5-2-4

Charmaz, K. (2006). Constructing Grounded Theory: A Practical Guide through Qualitative Analysis. Sage.

Cocola-Gant, A. (2015). Tourism and commercial gentrification. Post-Doctoral Researcher, Centre of Geographical Studies, University of Lisbon. Paper presented at the RC21 International Conference on "The Ideal City: between myth and reality. Representations, policies, contradictions and challenges for tomorrow's urban life". https://www.rc21.org/en/wp-content/uploads/2014/12/E4-C\%C3\%B3cola-Gant.pdf

Cocola-Gant, A. (2016). Holiday rentals: The new gentrification battlefront. Sociological Research Online, 21(3), 1-9. https://doi.org/10.5153/sro.4071

Cocola-Gant, A. (2018). Tourism Gentrification. In Lees, L. \& Phillips, M., Handbook of gentrification studies (pp. 281-293). Edward Elgar Publishing.

Corte-Real, M. (2016). Shaping a territory: Case study-The Moorish Quarter in Lisbon (Mouraria). Public Spaces: Times of Crisis and Change (Research in Urban Sociology, Vol. 15), Emerald Group Publishing Limited, 169-189. https://doi.org/10.1108/S1047004220160000015008

Cruz Lopes, A., Rodrigues, E. B., \& Vera-Cruz, R. (2019). Tourism Gentrification. IOP Conference Series: Materials Science and Engineering, 471(9), 1-6.

Dias, Á., González-Rodríguez, M. R., \& Patuleia, M. (2020). Developing poor communities through creative tourism. Journal of Tourism \& Cultural Change, 1-21. https://doi.org/10.1080/14766825.2020.1775623

Dobbs, R., \& Butler, R. (2019). Overtourism: Issues, realities and solutions. De Gruyer Studies in Tourism.

Doğan, H. Z. (1989). Forms of adjustment. Annals of Tourism Research, 16(2), 216-236. https://doi.org/10.1016/0160-7383(89)90069-8

Doxey, G. (1975). A causation theory of visitor-resident irritants: methodology and research

Elliott-Cooper, A., Hubbard, P., \& Lees, L. (2019). Moving beyond Marcuse: Gentrification, displacement and the violence of un-homing. Progress in Human Geography. https://doi.org/10.1177/0309132519830511

European Migration Network. EMN Glossary research: https://ec.europa.eu/homeaffairs/what-we-do/networks/european_migration_network/glossary_search_en

Ezzy, D. (2002). Qualitative analysis (p. xii-6). doi.org/10.4324/9781315015484

Fainstein, S. S. (2005). Cities and diversity. Urban Affairs Review, 41(1), 3-19. https://doi.org/10.1177/1078087405278968

Fincher, R., Iveson, K., Leitner, H., \& Preston, V. (2014). Planning in the multicultural city: Celebrating diversity or reinforcing difference? Progress in Planning, 92, 1-55. https://doi.org/10.1016/j.progress.2013.04.001

Flick, U., Kardoff, E. \& Steinke, I. (2004). A Companion to Qualitative Research. Sage Publications.

Foroutani, Y. (2020). Ethnic or Religious Identities?: Multicultural Analysis in Australia from Socio-Demographic Perspective. Journal of Ethnic and Cultural Studies, 7(1), 1-19. http://dx.doi.org/10.29333/ejecs/280

Fuarros, I. S. (2016). Ai, Mouraria!" Music, tourism, and urban renewal in a historic lisbon neighbourhood. MUSICultures, 43(2), 66-88.

Gheasi, M., Nijkamp, P., \& Rietveld, P. (2011). Migration and Tourist Flows. Tourism Economics, 111-126. https://doi:10.1007/978-3-7908-2725-5_8 
Glass, R. (1964). Aspects of Change. In Brown-Saracino, J., Gentrification Debates: A Reader (pp. 19-61). Routledge.

Goodwin, H. (2017). The challenge of overtourism [Working Paper 4]. Responsible Tourism Partnership.

Gotham, K. F. (2005). Tourism gentrification: The case of New Orleans' Vieux Carré (French Quarter). Urban Studies, $1099-1121$. https://doi.org/10.1080/00420980500120881

Gotham, K. F. (2018). Assessing and advancing research on tourism gentrification. OpenEdition Journals, Via Tourism Review. https://doi.org/10.4000/viatourism.2169

Gravari-Barbas, M., \& Guinand, S. (2017). Tourism and Gentrification in Contemporary Metropolises. International Perspectives. Routledge.

Grewal, I., Maher, A., Watters, H., Clemens, D., \& Webb, K. (2019). Rewriting Teacher Education: Food, Love, and Community. Journal of Culture and Values in Education, 2(3), 44-60. https://doi.org/10.46303/jcve.03.02.3

Grondeau, A., \& Pondaven, F. (2018). Le street art, outil de valorisation territoriale et touristique: L'exemple de Galeria Arte Urbana de Lisbonne. EchoGéo, (44). https://doi.org/10.4000/echogeo.15324

Gu, H., \& Ryan, C. (2008). Place attachment, identity and community impacts of tourism-the case of a Beijing hutong. Tourism Management, 29(4), 637-647. https://doi:10.1016/j.tourman.2007.06.006

Gurer, C. (2019). Refugee Perspectives on Integration in Germany. American Journal of Qualitative Research, 3(2), 52-70. https://doi.org/10.29333/ajqr/6433

Johnson, C., \& Hinton, H. (2019). Toward a Brillant Diversity. Journal of Culture and Values in Education, 2(1), 56-70. https://doi.org/10.46303/jcve.02.01.5

Jover, J., \& Díaz-Parra, I. (2019). Gentrification, transnational gentrification and touristification in Seville, Spain. Urban Studies. https://doi.org/10.1177/0042098019857585

Koens, K., \& Postma, A. (2017). Understanding and managing visitor pressure in urban tourism. Centre of Expertise, Leisure, Tourism \& Hospitality. Breda University of Applied Sciences.

Koens, K., Postma, A., \& Papp, B. (2018). Is overtourism overused? Understanding the impact of tourism in a city context. Sustainability, 10(12), 4384. doi:10.3390/su10124384

Koh, E., \& Fakfare, P. (2019). Overcoming "over-tourism": The closure of Maya Bay. International Journal of Tourism Cities, 6(2). 279-296. https://doi.org/10.1108/IJTC02-2019-0023

Krase, J. (2012). Seeing cities change: Local culture and class. City University of New York.

Kuščer, K., \& Mihalič, T. (2019). Residents' attitudes towards overtourism from the perspective of tourism impacts and cooperation-the case of Ljubljana. Sustainability, 11(6), 1823. https://doi.org/10.3390/su11061823

Kymlicka, W. (2012). Multiculturalism: Success, failure, and the future. Canada Research Chair in Political Philosophy, Queens University. Korea Foundation Global Seminar.

Lankford, S. V., \& Howard, D. R. (1994). Developing a tourism impact attitude scale. Annals of Tourism Research, 21(1), 121-139. https://doi.org/10.1016/0160-7383(94)90008-6

LaPaglia, K. (2018). Book Review: Critical pedagogy: Notes from the real world. American Journal of Qualitative Research, 2(2), 150-153.

Lees, L. (2000). A reappraisal of gentrification: Towards a "geography of gentrification." $\begin{array}{llll}\text { Progress in Human Geography, 24(3), 389-408. } & \end{array}$ https://doi.org/10.1191/030913200701540483

Lees, L., Slater, T. \& Wyly, E. (2013). Gentrification. Routledge. (pp. 3-36). 
Levrau, F., \& Loobuyck, P. (2018). Introduction: Mapping the multiculturalisminterculturalism debates. Comparative Migration Studies, 6(13). https://doi.org/10.1186/s40878-018-0080-8

Maxwell, R. (2010). Evaluating migrant integration: Political attitudes across generations in Europe. International Migration Review, 44(1), 25-52. https://doi.org/10.1111/j.17477379.2009.00797.x

Mendes, L. (2013). Public policies on urban rehabilitation and their effects on gentrification in Lisbon. Institute of Geography and Spatial Planning.

Milano, C., Novelli, M., \& Cheer, J. (2019). Overtourism and tourismophobia: A journey through four decades of tourism development, planning and local concerns. Tourism Planning \& Development, $16(4), \quad 353-357$. https://doi.org/10.1080/21568316.2019.1599604

Moufakkir, O. (2014). What's immigration got to do with it? Immigrant animosity and its effects on tourism. Annals of Tourism Research, 49, 108-121. https://doi.org/10.1016/j.annals.2014.08.008

Muler Gonzalez, V., Coromina, L., \& Galí, N. (2018). Overtourism: Residents' perceptions of tourism impact as an indicator of resident social carrying capacity - case study of a Spanish heritage town. Tourism Review, 73(3), 277-296. https://doi.org/10.1108/TR08-2017-0138

Parker, J. (2019). Second language learning and cultural identity. Journal of Curriculum Studies Research, 1(1), 33-42. https://doi.org/10.46303/jcsr.01.01.3

Pavel, F. (2016). El Bairro Alto en Lisboa entre gentrificacion, turistification y derechos de la poblacion. Contested Cities, Madrid, Spain.

Perkumienè, D., \& Pranskūnienè, R. (2019). Overtourism: Between the right to travel and residents' rights. Sustainability, 11(7), 2138. https://doi.org/10.3390/su11072138

Philips, M. (1993). Rural gentrification and the processes of class colonisation. Journal Rural Sturdies. 9(2), 123-140.

Pizam, A. (1978). Tourism's impacts: The social costs to the destination community as perceived by its residents. Journal of Travel Research, 16(4), 8-12. https://doi.org/10.1177/004728757801600402

Rath, J. (2007). The transformation of ethnic neighbourhoods into places of leisure and consumption, Working Paper 144. Institute for Migration \& Ethnic Studies (IMES), University of Amsterdam.

Rustenbach, E. (2010). Sources of negative attitudes toward immigrants in Europe: A multilevel analysis. International Migration Review, 44(1), 53-77. https://doi.org/10.1111/j.1747-7379.2009.00798.x

Safi, M. (2009). Immigrants' life satisfaction in Europe: Between assimilation and discrimination. European Sociological Review, 26(2), 159-176. https://doi.org/10.1093/esr/jcp013

Sequera, J., \& Nofre, J. (2018). New debates on touristification and the limits of gentrification. Shaken, not stirred. City, 22(5-6), 843-855. https://doi.org/10.1080/13604813.2018.1548819

Sequera, J., \& Nofre, J. (2019). Touristification, transnational gentrification and urban change in Lisbon: The neighbourhood of Alfama. Urban Studies, 1-21 https://doi.org/10.1177/0042098019883734

Seraphin, H., Ivanov, S., Dosquet, F., \& Bourliataux-Lajoinie, S. (2019). Archetypes of locals in destinations victim of overtourism. Journal of Hospitality and Tourism Management. https://doi:10.1016/j.jhtm.2019.12.001

Smelser, N. \& Baltes, P. (2001). International Encyclopedia of the Social \& Behavioral Sciences. Elsevier. 
Smith, A. (2020). Critical Race Theory: Disruption in Teacher Education Pedagogy. Journal of Culture and Values in Education, 3(1), 52-71. https://doi.org/10.46303/jcve.03.01.4

Tarman, B., \& Gürel, D. (2017). Awareness of social studies teacher candidates on refugees in Turkey. Journal of Social Studies Research, 41(3), 183-193. 10.1016/j.jssr.2016.11.001

Ujang, N. (2012). Place attachment and continuity of urban place identity. Procedia - Social \& Behavioral Sciences, 49, 156-167. https://doi.org/10.1016/j.sbspro.2012.07.014

Vertovec, S., Wessendorf, S. (2004). Cultural, Religious and Linguistic Diversity in Europe: an overview of issues and trends. In Penninx, R., Berger, M. \& Kraal, K., The Dynamics of International Migration and Settlement in Europe (pp.171-199). Springer.

Wachsmuth, D., \& Weisler, A. (2018). Airbnb and the rent gap: Gentrification through the sharing economy. Environment and Planning A: Economy and Space. https://doi.org/10.1177/0308518x18778038

Watters, S. M., Ward, C., \& Stuart, J. (2020). Does normative multiculturalism foster or threaten social cohesion? International Journal of Intercultural Relations, 75, 82-94. https://doi:10.1016/j.ijintrel.2020.02.001

Yigit, M.F. \& Tarman, B. (2013). The Impact of Social Media on Globalization, Democratization Citizenship, Journal of Social Science Education, 12(1), 75-80.

Yin, R. K. (1981). The case study as a serious research strategy. Knowledge, 3(1), 97-114. https://doi.org/10.1177/107554708100300106

\section{Notes on Contributors}

Pauline Daly. Ba in Applied Foreign Languages (English, Spanish and Chinese), MsC in Tourism. She worked in the tourism industry and studied in several countries (France, Ireland, Argentina and Portugal).

Álvaro Lopes Dias is a Professor of Strategy and Entrepreneurship at Universidade Lusófona and ISCTE-IUL, both in Lisbon, Portugal and a tourism researcher at Universidad de Sevilla. Ph.D. in Management and MBA in International Business. Professor Dias has over 26 years of teaching experience. He regularly teaches in English, Portuguese, and Spanish at undergraduate, master and doctorate levels, as well as in executive programs. Professor Dias has produced extensive research in the field of Tourism and Management, including books, book chapters, papers in scientific journals and conference proceedings, case studies, and working papers. ORCID: 0000-0003-4074-1586

Mafalda Patuleia. PhD in Tourism from the Faculty of Economics of the University of Algarve. Graduated in Tourism at INP and obtained a Master degree from ISCTE in Communication, Culture and Information Technologies. She is the Head of Tourism Department of the Lusófona Group and Dean of the Higher Institute of New Professions (INP), where she also teaches, among other subjects, Tourism Studies and Sociology of Leisure and Tourism. She is President of the Technical and Scientific Council of INP. She teaches at various national and foreign universities. She writes in several newspapers related to tourism. ORCID: 0000-0002-8401-1860 